\title{
CORRELATION BETWEEN PSYCHOLOGICAL WELL-BEING AND LEVEL OF RELIGIOSITY MANIFESTATION AT DIFFERENT AGES
}

\author{
Nadezhda Telepova \\ Russian Academy of Natural History, \\ State Autonomous Educational Institution of Higher Education \\ «Moscow City University: Samara Branch», Russian Federation

\section{Mikhail Telepov} \\ State Autonomous Educational Institution of Higher Education \\ «Moscow City University: Samara Branch», Russian Federation
}

\begin{abstract}
The influence of modern society non-stability due to different reasons (political, economic, epidemiological etc.) on people's well-being, mood and health is obvious. The objective of the study is the correlation between psychological well-being and religiosity manifestation of people at different ages. In our research we set the aim of studying and revealing the dynamics of correlation between these two categories while aging. Hypothesis of our research is that there is a dynamic of correlation associations while aging and there is strong positive association between psychological well-being and religiosity manifestation at second part of middle age and old age. We take religiosity as a deep personal structure, existential attitude which cannot be limited by definite religious confession but can be measured by manifestation factors. We conducted our research on the basis of Samara Methodist Church in 2018-2020. The sample includes 85 people, among them 22 at the age of 20-24(early adulthood), 20 at the age of 25-50(first part of middle age), 21 at the age of 51-64(second part of middle age, preretirement period), 18 at the age of 65-85 (old age). Study methods: observation, conversation, "Psychological well-being scales by Carol Ryff", authors' "questionnaire on religiosity manifestation", methods of mathematical statistics (Spearman's correlation coefficient). Analyzing the dynamics of the correlation between level of religiosity manifestation and psychological well-being we revealed that while aging there are quite different correlation data. There is no statistically significant association between General Index of Psychological well-being and level of religiosity manifestation at the ages of early adulthood and first part of middle age, but in the groups of participants of second part of the middle age and old age there is strong positive correlation.
\end{abstract}

Keywords: process of aging, psychological well-being, religiosity manifestation. 
Telepova \& Telepov, 2021. Correlation Between Psychological Well-Being and Level of Religiosity Manifestation at Different Ages

\section{Introduction}

The influence of modern society non-stability due to different reasons (political, economic, epidemiological etc.) on people's well-being, mood and health is obvious. At the same time people absorb life not only through the prism of outer conditions but also the prism of their religiosity, personal factors and age. In any age there are special features of taking things into consideration and absorbing reality. There are numerous researches on this topic (Dzhidar'jan, 2009; Allport, 2020; Erikson, 2013; Maslow, 2019 and others).

The idea of connection between religious thinking and psychological wellbeing was widely proclaimed in different researches (Frankl, 2019; Fromm, 2020; James, 2020; Melehov, 2011 and others). Religiosity is a deep personal structure, existential attitude which can not be limited by definite religious confession. In our research we define the category of religiosity not as some religious concept but as personal faith basis, personal determination which is revealed in definite manifestation. Religiosity in connection with psychological well-being of different ages is not much studied. In our research we set the goal of studying this correlation and revealing the dynamics of the connection between these two categories while aging.

Psychological well-being is a complex of evaluation of different life spheres. Social isolation, stress, interpersonal problems as well as political, economic, educational etc. factors destroy psychological well-being of a person (Dzhidar'jan, 2009,). On the other hand, spiritual and valuable orientations and self-concept are also very important in having sense of personal well-being: the numerous researches (Bredbern, 2005; Shevelenkova \& Fesenko, 2005 and others) tell that.

From the positive psychological functioning point of view well-being is closely connected with such criteria as "self-esteem", "self-determination", "selfrespect", a lot of researchers speak about that (Allport, 2020; Erikson, 2013; Jahoda, 2013; Maslow, 2019 and others). Carol. Ryff generalized the data of the theories and defined six main components of psychological well-being. They are: Autonomy, Environmental Mastery, Personal Growth, Positive Relations with Others, Purpose in Life, Self-acceptance. Carol. Ryff considers these components be connected with different structural elements of positive personal functioning (Ryff, 1997; Ryff, 2019).

Rail Shamionov in his studies uses the term "subjective well-being” defining personal attitude to one's own personality, to process of life which gives the sense of satisfaction (Shamionov, 2002). People evaluate their life according to cognitive and affectional explanations: whether your reality is close to what you consider ideal life. Non-satisfaction appears when there is a sense of gap between 
reality and ideal or when a person starts comparing himself to other people. Affect is an emotional site which can express both positive and negative feelings.

According to Ilona Boniwell subjective well-being is the most important part of person's predominant mood. System of one's attitudes is developed on the basis of beliefs setting the personal system of coordination which includes the most important events. This system includes inner and outer factors which are dynamic in time and form the wholeness of person's similar and different features (Boniwell, 2009). Ilona Boniwell offers the following formular:

Subjective well-being $=$ life satisfaction + affect.

According to Rail Shamionov the factors of social well-being as a part of psychological one is social dependence, personal characteristics, assurance in life, emotional state, social comfort, satisfaction with labor, values of future. They can change while aging. Religious component is a spiritual well-being: sense of belonging to spiritual culture, possibility to join the richness of spiritual culture, sense of life purpose, having faith (in God, in oneself, in luck etc.) (Shamionov, 2002). Faith has to do with spiritual well-being. Physical component is also important in well-being, it has to do with body-wellness. The state of health can be measured according to complex of parameters: clinical, physiological, social, geographical and others (Kulikov, 2000).

The scientific interest to religious part of personality is growing. There are lots of difficulties in research of religiosity as there is no definite approach to the terminology and methods which can show the objective picture of this phenomena. Valentin Rybin in his researches considers religion in social, historian, social and cultural aspects. According to his point of view religion includes the following:

1) religious thinking as personal, inner attitude to faith, eternal life, relations with God, etc.;

2) religious ceremonies as external appearance of religiosity (prayer, reading scriptures, fasting, attending church etc. ;

3) religious institutions including structures in charge providing worldview including morality, divinity, religious subordination etc.

In our research we use the questionnaire which contains these factors to determine the level of religiosity.

The role of religiosity in the process of decision making and absorbing the reality and self-concept is described in the works by Nadezhda Telepova and Mikhail Telepov. The authors describe the factors which lead people cross the line between religiosity and religious addiction and cross-cultural features connected with religiosity manifestation (Telepova, 2010; Telepova, 2019).

Victor Frankl in his works describes psychotherapy function of religion and religiosity. He says about compensatory and comforting mechanisms of religion (Frankl, 2018). 
Telepova \& Telepov, 2021. Correlation Between Psychological Well-Being and Level of Religiosity Manifestation at Different Ages

Dmitry Melechov in his researches stresses the fact that religiosity helps the person compensate his dependance on natural and social catastrophic events, get free from the sense of helplessness, offence and fear of death (Melechov, 2011).

Age is a factor that influences psychological well-being. Carol Ryff in her researches of psychological well-being says about specific features of world perception and self-perception by people of different ages (Ryff \& Heidrich, 1997; Ryff, 2019).

Eric Ericson speaks about psychological features connected with age: world perception, choice, character development (Ericson, 2013).

Hypothesis of our research is that there is a dynamic of correlation associations while aging and there is strong positive association between psychological well-being and religiosity manifestation at second part on middle age and old age.

\section{Method}

We conducted our research on the basis of Samara Methodist Church in 2018-2020. The sample includes 85 people, among them 22 participants at the age of 20-24(early adulthood), 20 participants at the age of 25-50(first part of middle age), 21 participants at the age of 51-64(second part of middle age, preretirement period), 18 participants at the age of 65-85 (old age). All participants (male and female) were members of the same religious institution, which made the sample homogeneous according to this aspect. We studied their level of religious manifestation on the aspects of religious thinking and religious ceremonies in connection with their psychological well-being. Participants at the age of 20-24 were all single, at the age of 25-64 - married. Participants at the old age are married and widowed. We asked the people of the church to help us in our research and offered them a questionnaire and "Psychological well-being scales by Carol Ryff". Young people preferred to do it in online regime, people at average and old ages preferred offline meetings after Sunday service.

We conducted our research in the period August 2018 - October 2020.

Carol Ryff's test includes six subscales, they are: Autonomy ("Even if my opinion is contrary to general consensus I have confidence in it"); Environmental Mastery ("I usually feel in charge of my life situation"); Personal Growth ("I open to knew experiences and new challenges"); Positive Relations With Others ("I am considered to be open and giving person , ready to share my time with people"); Purpose In Life ("I am not the one who wanders aimlessly through life"); Selfacceptance ("I am pleased how things have turned out in my life") (Ryff, 2019). We used «Ryff's scales of psychological well-being» which was adapted in 2005 by Tatiana Shevelenkova (Shevelenkova \& Fesenko, 2005) where four more subscales are taken into consideration: Affect Balance (subscribes general 
emotional evaluation of oneself and one's life); Sense of Life (shows the obsession of this sense); Person as Open System (shows ability to percept and integrate all the aspect of human being: positive and negative); Autonomy (ability to have balance between social and personal interests).

To determine level of manifestation of religiosity we used authors' questionnaire which reveals aspects of participants' religious thinking and religious ceremonies on the following issues: regularity of reading Holy Scriptures, prayers and fasting; wearing religious clothes or special religious attributes, attitude to religious holidays and traditions, level of knowledge of confession's dogma's, intention of raising children in definite religious tradition, religious leaders' authority acceptance.

Spearman's correlation coefficient helped us to find correlation between level of religiosity and psychological well-being of test subjects.

\section{Results}

In the first group (age of 20-24, period of early adulthood); we got the following results: general index of correlation between psychological well-being and level of religiosity manifestation is not statistically significant which means that there is no association between these categories.

But the research revealed a statistically significant reverse correlations between Level of religiosity and Environmental Mastering $\left(r_{s}=-.587, p \leq .01\right)$, Level of religiosity and Purpose in Life $\left(r_{s}=-.603, p \leq .01\right)$. Critical value of Spearman's criteria according to the sample is $\mathrm{r}_{\mathrm{s}}=.508(\mathrm{p} \leq .01)$

In the second group (age of 25-50, first part of middle age) general index of correlation between psychological well-being and level of religiosity manifestation is not statistically significant in this group either.

What about scales of psychological well-being the results are different: there is statistically strong positive correlation between Level of Religiosity and Sense of Life $\left(r_{s}=.592, p \leq .01\right)$; a statistically significant reverse correlations between Level of religiosity and Personal Growth $\left(\mathrm{r}_{\mathrm{s}}=.597, \mathrm{p} \leq .01\right)$, Level of religiosity and Affect Balance $\left(\mathrm{r}_{\mathrm{s}}=-.614, \mathrm{p} \leq .01\right)$.

In the third group (age of 51-64, second part of middle age, so-called preretirement age) general index of correlation between psychological well-being and level of religiosity manifestation is statistically significant; there is a statistically positive association between these categories $\left(\mathrm{r}_{\mathrm{s}}=.578, \mathrm{p} \leq .01\right)$.

Data in well-being scales: there is statistically strong positive correlation between Level of Religiosity and Personal Growth ( $\left.\mathrm{r}_{\mathrm{s}}=.564, \mathrm{p} \leq .01\right)$, Sense of Life $\left(r_{s}=.612, p \leq .01\right)$, Positive Relations $\left(r_{s}=.597, p \leq .01\right)$, Purpose in Life $\left(\mathrm{r}_{\mathrm{s}}=.572, \mathrm{p} \leq .01\right)$; there is a statistically significant reverse correlations between Level of religiosity and Autonomy $\left(\mathrm{r}_{\mathrm{s}}=-.530, \mathrm{p} \leq .01\right)$. 
Telepova \& Telepov, 2021. Correlation Between Psychological Well-Being and Level of Religiosity Manifestation at Different Ages

In the fourth group (age 65-85, old age) the coefficients in all the subscales are statistically significant; general index of correlation between psychological well-being and level of religiosity manifestation is statistically significant; there is a statistically positive association between these categories $\left(\mathrm{r}_{\mathrm{s}}=.710, \mathrm{p} \leq .01\right)$.

There is a statistically significant, positive strong association between Level of religiosity and Positive Relations $\left(\mathrm{r}_{\mathrm{s}}=.607, \mathrm{p} \leq .01\right)$, Environmental Mastering $\left(\mathrm{r}_{\mathrm{s}}=.690, \mathrm{p} \leq .01\right)$, Personal Growth $\left(\mathrm{r}_{\mathrm{s}}=.672, \mathrm{p} \leq .01\right)$, Purpose in Life $\left(\mathrm{r}_{\mathrm{s}}=.754\right.$, $\mathrm{p} \leq .01)$, Self-acceptance $\left(\mathrm{r}_{\mathrm{s}}=.610, \mathrm{p} \leq .01\right)$, Sense of Life $\left(\mathrm{r}_{\mathrm{s}}=.682, \mathrm{p} \leq .01\right)$; there is a statistically significant, reverse association between Level of religiosity and Autonomy $\left(\mathrm{r}_{\mathrm{s}}=-.610, \mathrm{p} \leq .01\right)$, Affect Balance $\left(\mathrm{r}_{\mathrm{s}}=-.622, \mathrm{p} \leq .01\right)$, Person as Open System $\left(\mathrm{r}_{\mathrm{s}}=-.710, \mathrm{p} \leq .01\right)$.

In Table 1 we show data revealed in our research on correlation between scales of psychological well-being and level of religiosity manifestation at different ages.

Table 1 Spearman Correlations Among Scales of Psychological Well-being and Level of Religiosity Manifestation at Different Ages

\begin{tabular}{|c|c|c|c|c|}
\hline & $\begin{array}{c}20-25 \text { (early } \\
\text { adulthood) }\end{array}$ & $\begin{array}{c}25-50 \text { (first part } \\
\text { of middle age) }\end{array}$ & $\begin{array}{c}\text { 51-64 (second part } \\
\text { of middle age) }\end{array}$ & $\begin{array}{c}65-85 \\
\text { (old age) }\end{array}$ \\
\hline Positive Relations & .409 & .498 & $.597^{* *}$ & $.607^{* *}$ \\
\hline Autonomy & -.204 & -.309 & $-.530^{*}$ & $-.610^{* *}$ \\
\hline $\begin{array}{c}\text { Environmental } \\
\text { Mastering }\end{array}$ & $-.587^{*}$ & .103 & .409 & $.690^{* *}$ \\
\hline Personal Growth & .376 & $.597^{* *}$ & $.564^{*}$ & $.672^{* *}$ \\
\hline Purpose in Life & $-.603^{* *}$ & .300 & $.572^{*}$ & $.754^{* *}$ \\
\hline Self-acceptance & -.203 & .309 & .467 & $.610^{* *}$ \\
\hline Affect Balance & .389 & $-.614^{* *}$ & $-.524^{*}$ & $-.622^{* *}$ \\
\hline Sense of Life & .287 & $.592^{* *}$ & $.612^{* *}$ & $.682^{* *}$ \\
\hline $\begin{array}{c}\text { Person as Open } \\
\text { System }\end{array}$ & .198 & -.315 & -.432 & $-.710^{* *}$ \\
\hline $\begin{array}{c}\text { General Index of } \\
\text { Psychological } \\
\text { well-being }\end{array}$ & .356 & .478 & $.578^{*}$ & $.710^{* *}$ \\
\hline
\end{tabular}

Note. ${ }^{*}$ correlation is significant at the .05 level, ${ }^{* *}$ correlation is significant at the .01 level

\section{Discussion and Conclusions}

Analyzing the dynamics of the correlation between level of religiosity manifestation and psychological well-being we revealed that while aging there are quite different correlation data. There is no statistically significant correlation between Psychological well-being and level of religiosity manifestation at the ages of early adulthood and first part of middle age, but in the groups of 
participants of second part of the middle age and old age there is strong positive correlation. While analyzing the dynamics of data in association between psychological well-being scales and level of religious manifestation we see the qualitative changes.

At the age of early adulthood, the obedience to parents and people with social status is cultivated in more religious families. On the one hand young people at this age are usually dependent on their parents, their well-being depends more on their family than on their religiosity and religious manifestation. On the the other hand this is the age of adulthood and dependence on parental religiosity prevents young people from mastering their life and goal-setting process.

At the age of 25- 50 (first part of middle age) personal and professional life of people is developing and reaches a definite level; dependence on the older generation loses its position including religiosity; religion is becoming more personal attribute at this age. There is no statistically significant association between Psychological well-being and level of religiosity manifestation at this age. This is time of active life and perspectives, level of religiosity doesn't influence the personal items such as building family, developing children, doing career. But such scales as personal growth, affect balance and sense of life are more revealed in life of people whose life is connected with religious institution and demands some religious manifestation among those who are involved in developing children (Sunday schools), care for parents (church ministries), meaningful activity (volunteering).

In the groups of participants of second part of the middle age and old age there is strong positive significant association between Psychological well-being and level of religiosity manifestation. At this age periods any person realizes very definitely the reality of death and end of existence. Religion has psychotherapeutic effect; it defeats fear of death and helps psychological wellbeing. As professor Boris Bratus' says, "Death is Trump card of any religion". Faith and religion give sense to life in all spheres of human being (Bratus', 2009). All scales of psychological well-being show the association with level of religiosity manifestation.

The data of our research can be used by psychologists, social workers, teachers and religious leaders in their practice, because understanding of religiosity influencing different aspect of life in the process of aging is crucial. There are lots of dogmas of religiosity connected with personal preferences and life priorities, but these dogmas have a lot to do with age. Psychological wellbeing is a very important factor which should be taken into consideration in any practice connected with enhancing of life quality as well as correlation with religiosity. Our research can be input into gerontology which is rapidly developing nowadays. Therapeutic function of religion has been proclaimed for a long time by many researchers: Dmitry Melechov, Boris Bratus', Victor Frankl. 
Telepova \& Telepov, 2021. Correlation Between Psychological Well-Being and Level of Religiosity Manifestation at Different Ages

This function is becoming more crucial while aging (Bratus', 2009; Melechov, 2011; Frankl, 2018).

\section{References}

Allport, G. W. (2020). Mind Control: Dark Psychology, Manipulation by Psychology, Persuasion and NLP. USA. Traverse City (Michigan): Independent Publisher.

Bocharova, E. E. (2008). Sootnoshenie emocional'nyh komponentov i kognitivnyh komponentov sub"ektivnogo blagopoluchija v raznyh uslovijah socializacii. Problemy social'noj psihologii lichnosti, 32-56.

Boniwell, I. (2019). Positive Psychology. USA. NY (NY): Open University Press.

Bratus, B. S. (2009). Psihologija i duhovnyj opyt. Konsul'tativnaja psihologija i psihoterapija, 17(3), 19-49. Retrieved from http://psyjournals.ru/mpj/2009/n3/Bratus.shtml

Bredbern, N. (2005). Struktura psihologicheskogo blagopoluchija. Jaroslavl': Infra.

Dzhidar'jan, I. A. (2009). Problema obshhej udovletvorennost'ju zhizn'ju: teoreticheskoe i empiricheskoe issledovanie. Soznanie lichnosti v krizisnom obshhestve. Moskva : Institut psihologii RAN.

Erikson, E. (2013). Dimensions of New Identity. USA. NY (NY): W.W.Norton and Company. Frankl, V. E. (2018). Man's Search for Ultimate Meaning. USA, NY (NY): Basic Books.

Fromm, E. (2020). Man for Himself: An Inquiry into the Psychology of Ethics (Routledge Classics). United Kingdom. Abingdon-on-Themes : Routledge \&Co.

Jahoda, M. (2013). Current concepts of positive mental health. India. New Delhi: Isha Books.

James, W. (2020). The Varieties of Religious Experience. USA. Traverse City (Michigan): Independent Publisher.

Kulikov, L.V. (2000). Determinanty udovletvorennosti zhizn'. In V.Ju.Bol'shakov (Ed.), Obshhestvo i politika (476-510). Sankt-Peterburg: Izd-vo S.-Peterburgskogo un-ta.

Maslow, A.H. (2019). Motivation and Personality (Design Your Life). India. New Delhi: Prabhat Prakashan.

Melehov, D. E. (2011). Psihiatrija i aktual'nye problemy duhovnoj zhizni. Psihiatrija i problemy duhovnoj zhizni. Moskva: Svjato-Fillaretovskij moskovskij vysshyj pravoslavno-hristanskij institut.

Rybin, V. A. (2007). Religioznaja ideja v sovremennoj pedagogike. Pedagogika, 4.

Ryff, C. D \& Heidrich, S.V. (1997). Experience and well-being Exploration on domains of life and how the matter. International Journal of behavioral development, 20, 193-206.

Ryff, C. D. (2019). How Healthy are We? A National Study of Well-Being at Midlife. USA. Chicago: University of Chicago Press.

Telepova, N. N. (2010). Religioznaja addikcija: psihologicheskie uslovija profilaktiki i iscelenija. Vestnik universiteta (Gosudarstvennyj universitet upravlenija), 17, 118-122.

Telepova, N. N. (2019). Features of Islam and Christianity representatives' intercultural universals. Society. Integration. Education. Proceedings of the International Scientific Conference. May 24th-25th, Vol VII. 143-152. http://dx.doi.org/10.17770/sie2019 vol7.3915

Shamionov, R.M. (2002). Psihologija sub"ektivnogo blagopoluchija. Mir psihologii, 2, 143-148.

Shevelenkova, T.D., \& Fesenko, T.P. (2005). Psihologicheskoe blagopoluchie lichnosti. Psihologicheskaja diagnostika, 3, 95-121. 